\title{
The U-Pb age of the Finse batholith, a composite bimodal Sveconorwegian intrusion
}

\author{
Erik Jensen ${ }^{1,2} \&$ Fernando Corfu' \\ ${ }^{1}$ Department of Geosciences \& Centre for Earth Evolution and Dynamics (CEED), University of Oslo, P.O. Box 1047 Blindern, 0316 Oslo, Norway. \\ ${ }^{2}$ Present address: Statens vegvesen, Stavanger.
}

E-mail corresponding author (Fernando Corfu):fernando.corfu@geo.uio.no

The Sveconorwegian autochthonous basement in the Finse area, South Norway, comprises a c. $900 \mathrm{~km}^{2}$ bimodal batholith, dominated by K-feldspar megacrystic granite. The granite is locally intermingling with gabbroic rocks, and cut by different generations of pegmatite and aplite dykes. Zircon $\mathrm{U}-\mathrm{Pb}$ geochronological data obtained by ID-TIMS demonstrate that granite, granodiorite and gabbro are coeval, as they define a common upper intercept age of $985.6 \pm 1.6 \mathrm{Ma}$, dating emplacement of the batholith. Titanite is variously disturbed by later Sveconorwegian events. Pegmatites cross-cutting all structures yield zircon and titanite ages of $976 \pm 8 \mathrm{Ma}, 939 \pm 2$, and possibly $958 \pm 2 \mathrm{Ma}$, reflecting the latest stages of the evolution of the batholith. The Finse batholith is one of the earliest members of the widespread ferroan hornblende-biotite-granitoid (HBG) suite, in the western part of the Sveconorwegian orogen.

Keywords: batholith, bimodal magmatism, Sveconorwegian, U-Pb geochronology, zircon, titanite

Received 14. November 2015 / Accepted 13. April 2016 / Published online 3. May 2016

\section{Introduction}

The Precambrian basement of southwestern Norway formed between 1500 and $900 \mathrm{Ma}$, an evolution concluded by the widespread emplacement of intrusive rocks across the orogen (e.g., Bingen et al., 2008; Slagstad et al., 2013a). The latter are grouped into different suites with different ages, compositional characteristics, and geneses, as elaborated below. To obtain a clear picture of the evolution of this crust, and the relationships to other terranes in Baltica and other cratons, it is important to characterise and date these plutons.

The area underneath Hardangerjøkulen in Finse, Hallingdal, comprises a prominent coarse-grained and mostly massive granite. The rock has also played an important role as construction material for housing and bridges during the establishment of the railway some 100 yeas ago. Mapping of the area as part of a
MSc thesis (Jensen, 2012) has permitted observation of the relationships between this locally dominant granitic facies and other felsic and mafic phases and their structural state. In this paper we report some of the key observations, and $\mathrm{U}-\mathrm{Pb}$ ages for the main phases of the batholith and for one late pegmatite suite. The results are then discussed in the context of the tectonic relationships and inferred processes responsible for the development of the Sveconorwegian orogen in the region.

\section{The Finse magmatic complex}

Finse lies in the Hardangervidda sector of the Telemarkia Terrane, west of the Mandal-Ustaoset Fault and Shear Zone, which separates it from the Telemark sector (Fig. 1; Bingen et al., 2008). The autochthonous basement 

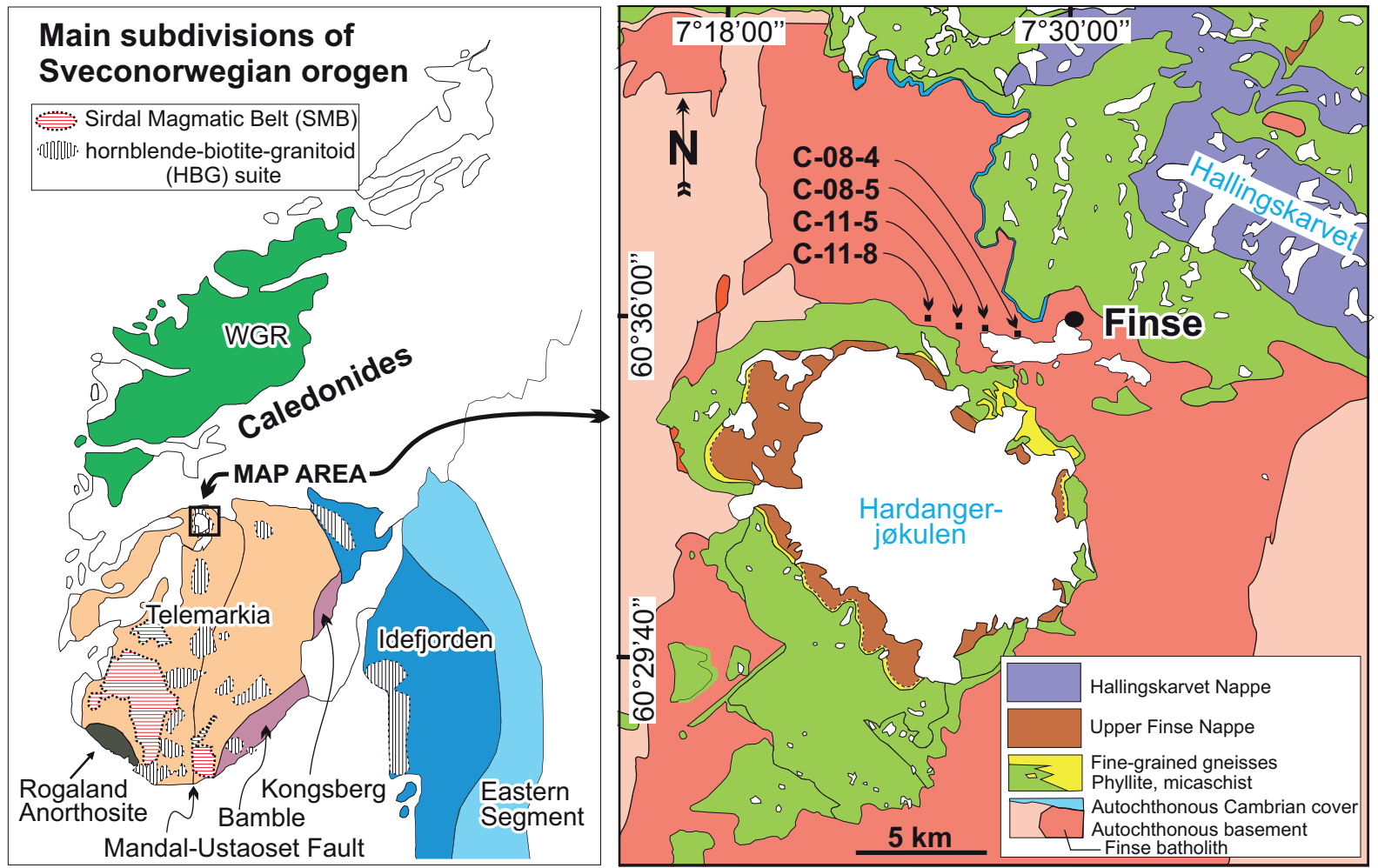

Figure 1. Left side: Large-scale map of the Sveconorwegian orogen showing the main subdivisions (after Bingen et al., 2005), the approximate distribution of the main plutonic suites (SMB and HBG), and location of the Finse area. The Mandal-Ustaoset Fault divides Telemarkia into the Telemark sector to the east and the Hardangervidda sector to the west. Right side: Geological map of the Finse area with sample locations (simplified from Sigmond, 1998; Roffeis \& Corfu, 2014). Abbreviation: WGR - Western Gneiss Region.

exposed around Finse, underneath the Palaeozoic sedimentary cover and Caledonian nappes, is dominated by intrusive rocks with subordinate occurrences of supracrustal rocks (Sigmond, 1998; Henriksen, 2000; Askvik, 2008). The most characteristic type of rock of the intrusive complex is a very coarse-grained feldspar-megacrystic granite, with 1-3 cm-long feldspar phenocrysts (Fig. 2A). The mineralogical composition of the granite and its retrogression were described in detail in Goldschmidt (1912), who also listed a major element analysis. This coarse facies ranges locally into equigranular, medium- to fine-grained granite, the feldspar phenocrysts becoming sparse or fully disappearing. Other parts of the complex, however, show a high degree of complexity involving finegrained gabbro (Fig. 2B-E), locally with sparse feldspar phenocrysts (Fig. 2D), and various types of fine-grained felsic rocks and pegmatites. There is local evidence of gabbro intruding granite and vice versa, of mingling of mafic and felsic magmas (Fig. 2C), and sedimentary structures reflecting magma chamber convection (Fig. 2F). Mafic rocks are mostly fine grained, but coarse gabbro is also observed locally in an area west of Finse Lake where it is associated with medium-grained granodiorite. There is no sharp boundary between gabbro and granodiorite suggesting that the transition is due to fractional crystallisation, but the granodiorite also contains mafic xenoliths.
The main megacrystic granite facies is commonly massive and without oriented structures, but locally there is also evidence for deformation and oriented emplacement of dykes (Fig. 2G-I). There are several generations of pegmatite dykes, the earliest one highly deformed (Fig. 2H-I), whereas the youngest dykes are straight and without evidence of deformation.

The extent and geometry of the batholith is not yet well known, but the specific granitic units can be traced for several tens of kilometres in the area of Hardangerjøkulen suggesting a size of over $900 \mathrm{~km}^{2}$ (Sigmond, 1998; Henriksen, 2000; Askvik, 2008).

The basement was eventually uplifted, eroded down, forming a regolith which is locally preserved as a zone of weathering and alteration a few metres thick, with typical rustiness, and the local development of a basal conglomerate (Goldschmidt, 1912; Gabrielsen et al., 2015).

\section{Analytical procedure}

The analyses were carried out by the ID-TIMS U$\mathrm{Pb}$ technique (Krogh, 1973). Zircon and titanite were separated by crushing, pulverising, Wilfley table, 

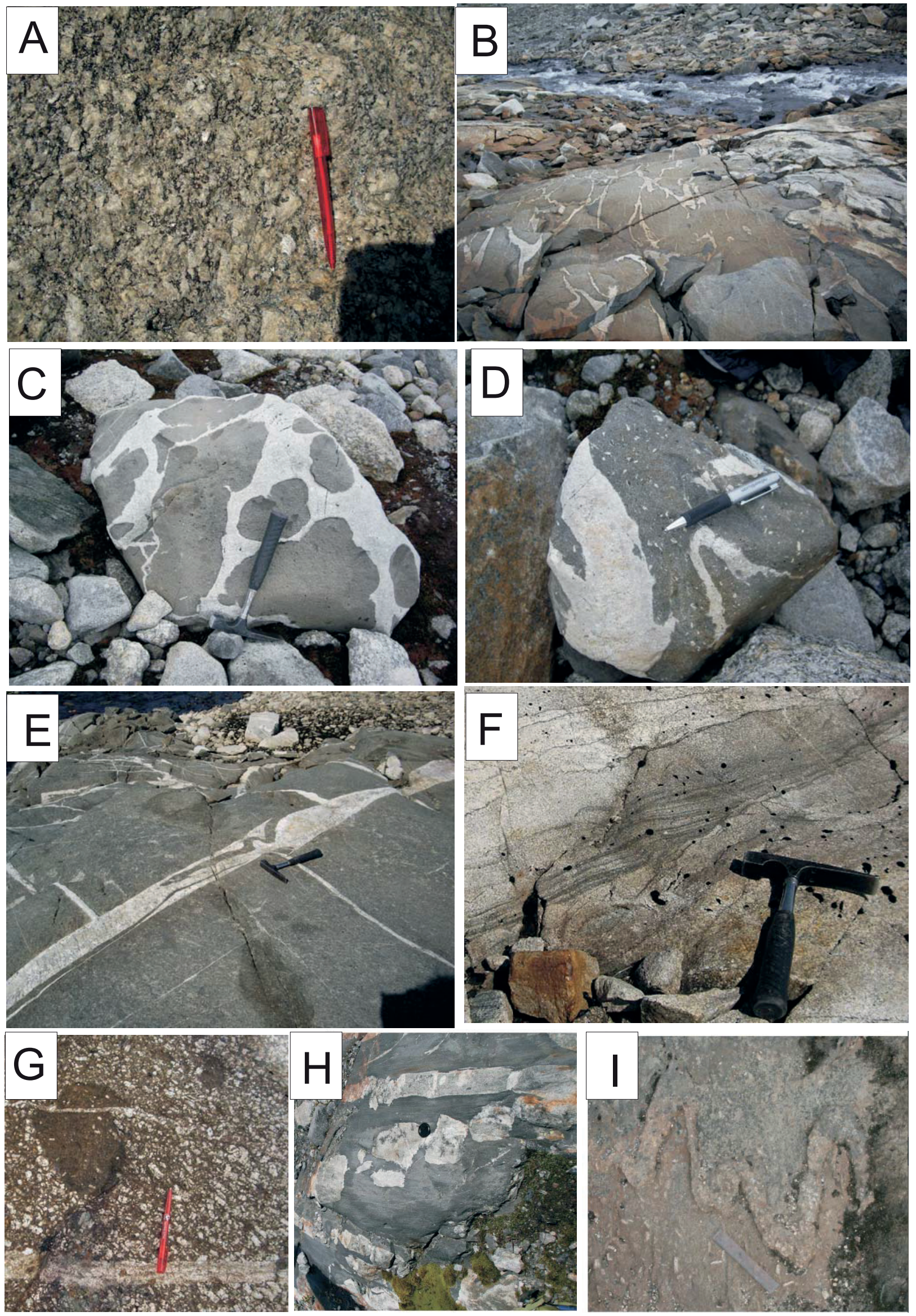

Figure 2. (A) Typical coarse-grained megacrystic granite, (B) net-veined fine-grained gabbro, $(C-D)$ mingling of mafic and felsic components, (E) feldspar-phyric veined gabbro; late granitic veins in gabbro, $(F)$ primary cross-bedding in granite, $(G)$ mafic xenoliths and late felsic veins, $(H)$ boudinaged felsic dykes in gabbro, (I) folded felsic dyke in gabbro. 
magnetic separation and heavy liquids. Suitable grains were subjected to either air abrasion (zircon and titanite; Krogh, 1982) or chemical abrasion (zircon; Mattinson, 2005). The grains were dissolved in HF, after addition of a mixed ${ }^{202} \mathrm{~Pb}-{ }^{205} \mathrm{~Pb}-{ }^{235} \mathrm{U}$ spike, and processed through ion exchange resin separation and solid source mass spectrometry. Details are described in Corfu (2004). The data are calculated with the decay constants of Jaffey et al. (1971) and plot with the program of Ludwig (2009). Initial common $\mathrm{Pb}$ has been corrected with compositions estimated with the model of Stacey \& Kramers (1975).

\section{Samples}

Four samples were investigated in this study. Sample C-08-4 represents the typical coarse-grained megacrystic granite (Figs. 1, 2A), C-11-5 is granodiorite, and $\mathrm{C}-08-5$ a coarse-grained gabbro. Sample C-11-8 represents late pegmatites which cross-cut all visible structures and phases and are themselves essentially undeformed. The sample consisted of pieces collected from different dykes and dykelets in the same outcrop.

\section{Zircon characteristics and U-Pb data}

The granite contains abundant zircon crystals, dominantly brownish and translucent to opaque, and prismatic $(1 / \mathrm{w}=2$ to $>5)$. The crystal faces are of variable type, but well developed $\{100\}$ and $\{101\}$ faces are most common. Cores are visible in some of the zircon grains. Five analyses carried out on selections of the grains, either air abraded or chemically abraded, are 1 to $7 \%$ discordant (Table 1, Fig. 3). They define a discordia line with intercept ages of $368 \pm 26$ and $986.7 \pm 1.9 \mathrm{Ma}$ (MSWD $=0.38$ ). The lower intercept age is consistent with $\mathrm{Pb}$ loss during the Caledonian orogeny.

The zircon population in the granodiorite sample is also abundant and prismatic as in the granite, but less strongly coloured. The morphology is dominated by $\{100\}$ and $\{101\}$ faces with euhedral to, in part, nearly anhedral outlines. Inclusions of other minerals are ubiquitous. Four of the analyses, both air and chemically abraded, are about $1 \%$ discordant and a fifth $4.5 \%$ discordant. Together they define a line with intercepts of $36 \pm 84$ and $980.1 \pm 1.6 \mathrm{Ma}(\mathrm{MSWD}=0.91)$. The trajectory, however, is strongly influenced by the more discordant analysis ( $\mathrm{x}$ in Fig. 3), the other four points fitting on the same line as the granite results, suggesting some superimposed younger $\mathrm{Pb}$ loss or an inherited component affecting the discordant fraction.

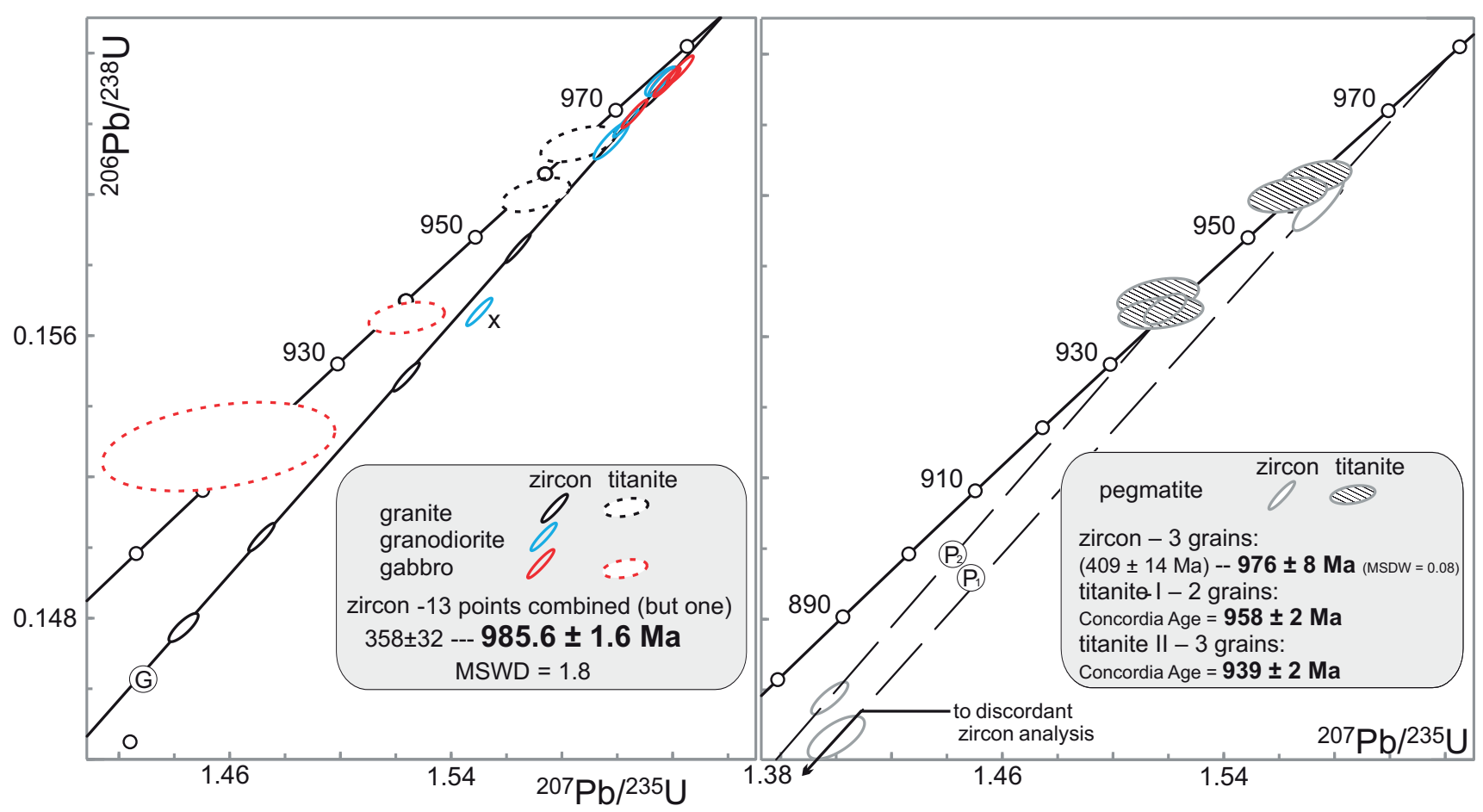

Figure 3. Concordia plots with zircon and titanite data for the various phases of the Finse batholith. Ellipses indicate 2 sigma uncertainty. Analysis $x$ not included in the main regression line $(G)$ yielding the main age of emplacement of the granite-granodiorite-gabbro complex at 985.6 $\pm 1.6 \mathrm{Ma}$. Lines P1 and P2 are calculated from subsets of data from the pegmatites; see text for details. 


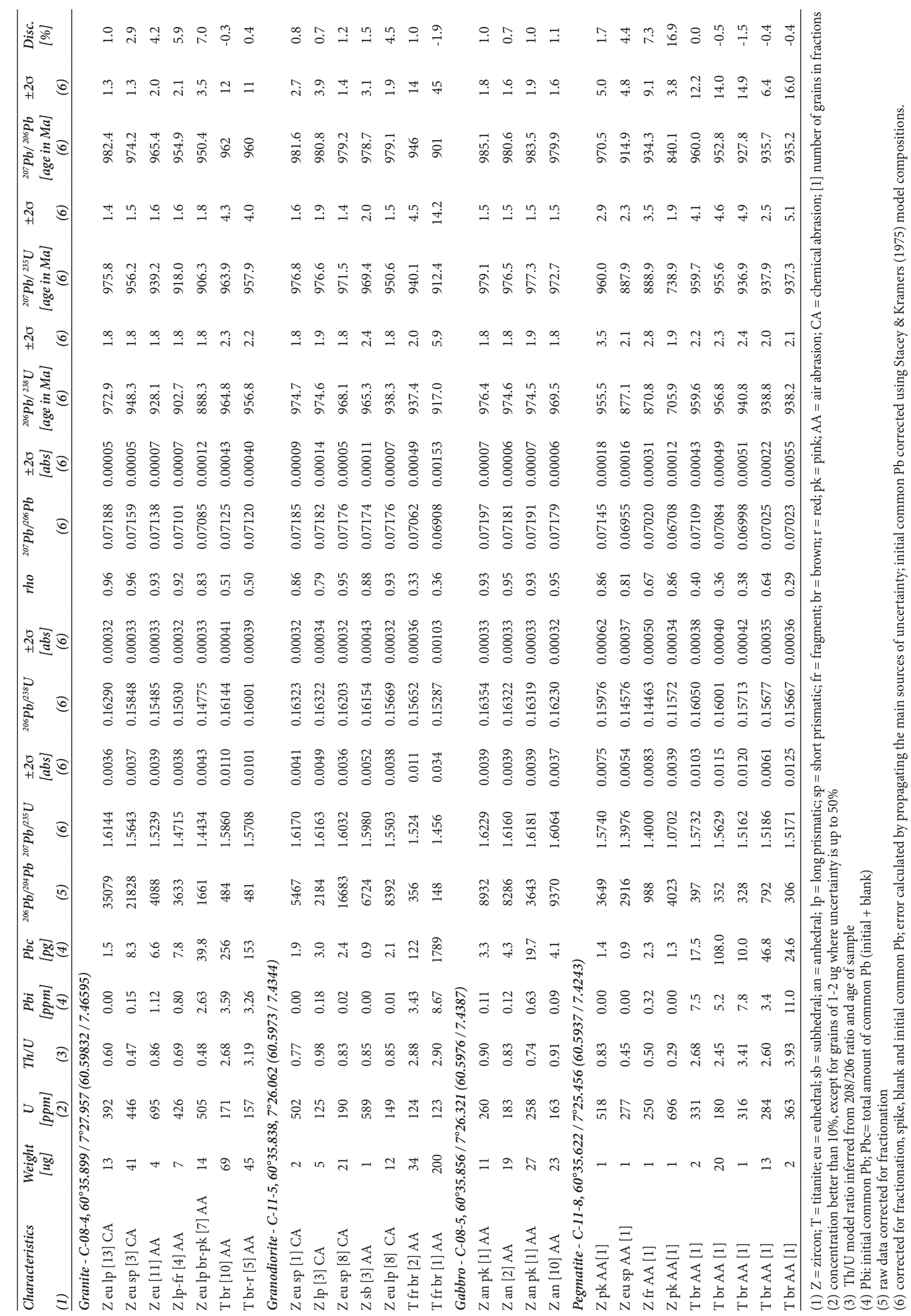


The zircon grains from the gabbro are mostly anhedral and in part irregular. The four analyses are clusterd together and when regressed from a Caledonian lower intercept age of $400 \pm 40 \mathrm{Ma}$ yield an upper intercept age of $986.4 \pm 4.3 \mathrm{Ma}(\mathrm{MSWD}=4.4)$.

Regression of all the thirteen zircon data from the three samples together, except for the discordant analysis in the granodiorite, yields a line with intercepts at $358 \pm 32$ and $985.6 \pm 1.6 \mathrm{Ma}$ (MSWD = 1.8; line G in Fig. 3).

The pegmatite sample contains relatively few, predominantly metamict and zoned zircon grains together with brown-red titanite. Four zircon analyses were carried out on air abraded euhedral crystals and fragments. The results are variously discordant; three of the analyses define a discordia line with intercepts at 976 $\pm 8 \mathrm{Ma}$ and $409 \pm 14 \mathrm{Ma}$ (MSWD $=0.08$ : line $\mathrm{P}_{1}$ in Fig. 3 ), interpreted as indicating the time of crystallisation and of Caledonian $\mathrm{Pb}$ loss. Another zircon data point, however, deviates to the left of this line. The titanites are rich in $\mathrm{U}$ (up to $360 \mathrm{ppm}$ ) and $\mathrm{Th}$ (Th/U up to 3.9), and also in common $\mathrm{Pb}(3-11 \mathrm{ppm})$. The analyses plot in two groups, two grains indicating $958 \pm 2 \mathrm{Ma}$ and three others $939 \pm 2 \mathrm{Ma}$. The latter group coincides with a titanite analysis from the gabbro, but that could be a coincidence. More importantly, the titanite data fit on a line through the deviating zircon analysis mentioned above and projecting to a Caledonian lower intercept age (line P2 in Fig. 3). These relationships suggest that $939 \mathrm{Ma}$ is the age of intrusion of one of the pegmatite dykes. The significance of the $958 \mathrm{Ma}$ titanite date is more uncertain, and may reflect partial resetting. This is evident in two other titanite analyses of the granite and the gabbro that clearly postdate the initial magmatic crystallisation. The effect of a superimposed Caledonian $\mathrm{Pb}$ loss on the most reset analysis is possible but would have been of restricted magnitude.

\section{Discussion}

The concluding period of the Sveconorwegian orogeny in the Telemarkia Terrane was accompanied by widespread plutonic activity lasting close to 150 m.y. Three main plutonic associations have been recognised: (1) the Sirdal Magmatic Belt (SMB), including the Feda-Fennefoss suite, formed between 1060 and $1020 \mathrm{Ma}$ (Bingen et al., 2008, 2015; Vander Auwera et al., 2011; Slagstad et al., 2013a; Coint et al., 2015); (2) the hornblende-biotitegranitoid suite (HBG), formed between 990 and 920 Ma (Bingen et al., 2008; Vander Auwera et al., 2011); and (3) the anorthosite-mangerite-charnockite suite formed between 950 and $920 \mathrm{Ma}$ (Schärer et al., 1996; Vander Auwera et al., 2011). The SMB is a calc-alkaline, magnesian association whereas the HBG is more alkaline and ferroan (Slagstad et al., 2013a).
The chemical analysis available for the Finse granite (Goldschmidt, 1912) indicates a ferroan affinity confirming a link between the batholith and the HBG suite. The age of $985.6 \pm 1.6 \mathrm{Ma}$ places it as one of the oldest of the suite as the age is within error of the $989 \pm$ $9 \mathrm{Ma}$ age of the Grimstad granite (Kullerud \& Machado, $1991)$ and $990 \pm 14 \mathrm{Ma}$ of the Torsdalfjell granite (Andersen et al., 2007). Interestingly, granites with a similar appearance in the more immediate regions at Flå, Øye and Eidsfjord are much younger at about $930 \mathrm{Ma}$ (Priem et al., 1976 (Rb-Sr whole-rock age); Corfu, 1980; Bingen et al., 2008). These younger intrusions, however, seem to lack the mafic components typical of the Finse batholith.

Contrasting models have been proposed for the tectonic setting and causes of this magmatic progression. Bingen et al. (2008) view the SMB as the synorogenic products of either the closing stages of a continental arc or crustal thickening related to an oblique continentcontinent collision. Burial during this event caused the regional metamorphism, reaching locally granulitegrade conditions. The HBG suite is then interpreted as a function of the subsequent relaxation with gravitational collapse and upwelling of astenospheric mantle, the shorter-lived anorthosite-mangerite-charnockite plutonism indicating melting of dry and reduced lower crust whereas the HBG is attributed to melting of wet and oxidized lower crust (Vander Auwera et al., 2011). The contrasting view advanced by Slagstad et al. (2013a) considers the SMB suite instead as a Cordilleran-type, subduction-related, plutonic complex. The post-SMB lull in magmatic activity is attributed to flattening of the slab, with renewed steep subduction and presumably stepping back of the slab causing some delamination and back-arc activity which then produces the HBG suite.

Both models have merits and problematic aspects. Möller et al. (2013) pointed out that the eastern parts of the orogen exhibit much evidence for collisional tectonics, including thick and extensive mylonite zones indicating SE transport and subsequent extension. Crustal imbrication and deep burial creating highpressure rocks are also indicative of convergent processes; and they also emphasise the difficulty of achieving ultrahigh-temperature metamorphism, such as is observed in Rogaland at about $1010 \mathrm{Ma}$, in a 'cold' subduction environment. Coint et al. (2015), however, concluded that these ultrahigh-temperature processes were likely of local rather than of regional extent. Slagstad et al. (2013a, b) argued, furthermore, that the magmatic and metamorphic record of the western part of the Sveconorwegian orogen is most compatible with long-lived accretionary processes in an Andean-type subduction setting, stressing in particular that there is no direct evidence in that part of the orogen for crustal thickening and collision with another continent. The difference in apparent tectonic regimes between the eastern and western domains of the Sveconorwegian 
orogen may reflect relatively late amalgamation of crustal blocks (Coint et al., 2015). A separate evolution between Telemarkia and the rest of the orogen, and their eventual collision, has been considered before (e.g., Bingen et al., 2005). Although controversial (e.g., Andersen et al., 2004), the concept may yet provide the best explanation for the conflicting tectonic features observed across the Sveconorwegian orogen.

Some relevant information on the Sveconorwegian tectonic processes is also available in the overlying Caledonian allochthons. The Hardangervidda-Ryfylke Nappe Complex, which in the Silurian was thrust over autochthonous basement and its cover, includes the Kvitenut and Dyrskard nappes. The Kvitenut Nappe has a Gothian affinity, such as the crust in the Sveconorwegian foreland to the west and north, and was thrust on top of the Dyrskard Nappe, which has a Telemarkian affinity (Roffeis et al., 2013). Thrusting occurred at around 1000 $\mathrm{Ma}$ and the suture was stitched by an essentially coeval synorogenic granite. The pre-thrusting position of the nappe complex is uncertain, but it is reasonable to assume that it was located in the projection of the present boundary between the two terranes. The important point in this context is that the time at around $1000 \mathrm{Ma}$ corresponded, at least locally, to convergence and terrane juxtapositions, combined with metamorphism and some magmatism. Such a process would seem to fit better a continent collisional setting, but terrane aggregation during accretional processes would also be a viable solution.

Two important observations in the Finse batholith are (1) the bimodal nature of the intrusion and (2) the evidence for the oriented emplacement of mafic and felsic dykes associated with the batholith (Jensen, 2012). The first point implies the availability of sources for the mafic material, most likely the mantle with basaltic magma rising and mingling with crustal melts from the lower crust. Future isotope analyses should contribute to verify this inference. The contribution from mantle and lower crust is consistent with both the back-arc and the extension-delamination hypothesis. It is also consistent with the isotope geochemical characteristics of the HBG suite (Andersen et al., 2009). Vander Auwera et al. (2011), however, postulated a provenance of the more juvenile component by melting of underplated mafic crust. The second point, the orientation of small intrusive bodies and their local deformation indicating emplacement in a stress regime, is indicative of a compressional setting, a feature already evident by the general $\mathrm{N}-\mathrm{S}$ arrangement of the plutons on the larger scale of the craton (Coint et al., 2015). These features are in principle compatible with aspects of both models presently under discussion.

\section{Conclusions}

The Finse batholith is a bimodal magmatic complex emplaced at $985.6 \pm 1.6 \mathrm{Ma}$ in Telemarkian crust. It was followed by discrete events of pegmatite emplacement, at least two of which are reflected by the data in this paper at $976 \pm 8 \mathrm{Ma}$ and $939 \pm 2 \mathrm{Ma}$. The bimodal composition implies mixing of crustal and mantle derived magmas. Other features of the batholith also suggest emplacement in a compressional regime.

Acknowledgements. We are grateful to Gunborg Bye Fjell for help in the preparation of the samples. Fieldwork benefited from financial support from Småforsk grants. Reviews by Bernard Bingen and editor Trond Slagstad are gratefully acknowledged.

\section{References}

Andersen, T., Griffin, W.L., Jackson, S.E., Knudsen, T.-L. \& Pearson, N.J. 2004: Mid-Proterozoic magmatic arc evolution at the southwest margin of the Baltic Shield. Lithos 73, 289-318.

Andersen, T., Graham, S. \& Sylvester, A.G. 2007: Timing and tectonic significance of Sveconorwegian A-type granitic magmatism in Telemark, southern Norway: new results from laser-ablation ICPMS U-Pb dating of zircon. Norges geologiske undersøkelse Bulletin 447, 17-31.

Andersen, T., Graham, S. \& Sylvester, A.G. 2009: The geochemistry, $\mathrm{Lu}-\mathrm{Hf}$ isotope systematics, and petrogenesis of Late Mesoproterozoic A-type granites in southwestern Fennoscandia. Canadian Mineralogist 47, 1399-1422.

Askvik, H. 2008: Berggrunnskart Hardangerjøkulen 1416 II, scale 1:50,000, Norges geologiske undersøkelse.

Bingen, B., Skår, Ø., Marker, M., Sigmond, E.M.O., Nordgulen, Ø., Ragnhildstveit, J., Mansfeld, J., Tucker, R.D. \& Liégeois, J.-P. 2005: Timing of continental building in the Sveconorwegian orogen, SW Scandinavia. Norwegian Journal of Geology 85, 87-116.

Bingen, B., Nordgulen, O. \& Viola, G. 2008: A four-phase model for the Sveconorwegian orogeny, SW Scandinavia. Norwegian Journal of Geology 88, 43-72.

Bingen, B., Corfu, F., Stein, H.J. \& Whitehouse, M.J. 2015: U-Pb geochronology of the syn-orogenic Knaben molybdenum deposits, Sveconorwegian orogen, Norway. Geological Magazine 152, 537556. doi: 10.1017/S001675681400048X.

Coint, N., Slagstad, T., Roberts, N.M.W., Marker, M., Røhr, T. \& Sørensen, B.E. 2015: The Late Mesoproterozoic Sirdal Magmatic Belt, SW Norway: Relationships between magmatism and metamorphism andimplications for Sveconorwegian orogenesis. Precambrian Research 265, 57-77. doi: 10.1016/j.precamres.2015.05.002.

Corfu, F. 1980: U-Pb and Rb-Sr systematics in a polyorogenic segment of the Precambrian shield, central southern Norway. Lithos 13, 305323.

Corfu, F. 2004: U-Pb Age, Setting and Tectonic Significance of the Anorthosite-Mangerite-Charnockite-Granite Suite, LofotenVesterålen, Norway. Journal of Petrology 45, 1799-1819. doi: 10.1093/petrology/egh034.

Gabrielsen, R.H., Nystuen, J.P., Jarsve, E.M. \& Lundmark, A.M. 2015: The Sub-Cambrian Peneplain in southern Norway: its geological significance and its implications for post-Caledonian faulting, 
uplift and denudation. Journal of the Geological Society 172, 777791. doi: 10.1144/jgs2014-154.

Goldschmidt, V.M. 1912: Geologisch-petrographische Studien im Hochgebirge des südlichen Norwegens. I. Ein kambrisches Konglomerat von Finse und dessen Metamorphose. Skrifter Videnskaps Akademie, Matematisk Naturvitenskapelige Klasse 18, 1-19.

Henriksen, H. 2000: Berggrunnskart Myrdal 1416 III, scale 1:50,000, Norges geologiske undersøkelse.

Jaffey, A.H., Flynn, K.F., Glendenin, L.E., Bentley, W.C. \& Essling, A.M. 1971: Precision measurement of half-lives and specific activities of ${ }^{235} \mathrm{U}$ and ${ }^{238} \mathrm{U}$. Physical Review C4, 1889-1906.

Jensen, E. 2012: Geology and geochronology of the Hardangerjøkulen Klippe and its basement. MSc thesis, University of Oslo, 102 pp.

Krogh, T.E. 1973: A low-contamination method for hydrothermal decomposition of zircon and extraction of $\mathrm{U}$ and $\mathrm{Pb}$ for isotopic age determinations. Geochimica et Cosmochimica Acta 37, 485-494. doi: 10.1016/0016-7037(73)90213-5.

Krogh, T.E. 1982: Improved accuracy of U-Pb zircon ages by the creation of more concordant systems using an air abrasion technique. Geochimica et Cosmochimica Acta 46, 637-649.

Kullerud, L. \& Machado, N. 1991: End of a controversy: U-Pb geochronological evidence for significant Grenvillian activity in the Bamble area, Norway. Terra Abstracts, supplement to Terra Nova 3, p. 504.

Ludwig, K.R. 2009: Isoplot 4.1. A geochronological toolkit for Microsoft Excel, Berkeley Geochronology Center Special Publications, Volume 4.

Mattinson, J.M. 2005: Zircon U-Pb chemical abrasion ("CA-TIMS") method: Combined annealing and multi-step partial dissolution analysis for improved precision and accuracy of zircon ages. Chemical Geology 220, 47-66. doi: 10.1016/j.chemgeo.2005.03.011.

Möller, C., Bingen, B., Andersson, J., Stephens, M.B., Viola, G. \& Schersten, A. 2013: A non-collisional, accretionary Sveconorwegian orogen - comment. Terra Nova 25, 165-168.

Priem, H.N.A., Boelrijk, N.A.I.M., Hebeda, E.H., Verdurmen, E.A.Th. \& Verschure, R.H. 1976: Isotope geochronology of the Eidfjord Granite, Hardangervidda, West Norway. Norges geologiske undersøkelse 327, 35-39.

Roffeis, C. \& Corfu, F. 2014: Caledonian nappes of southern Norway and their correlation Sveconorwegian basement domains. In Corfu, F., Gasser, D. \& Chew, D.M. (eds.): New Perspectives on the Caledonides of Scandinavia and Related Areas, Geological Society of London Special Publications 390, pp. 193-221. doi: 10.1144/ SP390.13.

Roffeis, C., Corfu, F. \& Gabrielsen, R.H. 2013: A Sveconorwegian terrane boundary in the Caledonian Hardanger-Ryfylke Nappe Complex: the lost link between Telemarkia and the Western Gneiss Region? Precambrian Research 228, 20-35. doi: 10.1016/j.precamres.2013.01.008.

Schärer, U., Wilmart, E. \& Duchesne, J.C. 1996: The short duration and anorogenic character of anorthosite magmatism: $\mathrm{U}-\mathrm{Pb}$ dating of the Rogaland complex, Norway. Earth and Planetary Science Letters $139,335-350$.

Sigmond, E.M.O. 1998: Berggrunnskart Odda, scale 1:250,000, Norges geologiske undersøkelse.

Slagstad, T., Roberts, N.M.W., Marker, M., Røhr, T.S. \& Schiellerup, H. 2013a: A non-collisional, accretionary Sveconorwegian orogen. Terra Nova 25, 30-37.

Slagstad, T., Roberts, N.M.W., Marker, M., Røhr, T.S. \& Schiellerup, H. 2013b: A non-collisional, accretionary Sveconorwegian orogen reply. Terra Nova 25, 169-171.

Stacey, J.S. \& Kramers, J.D. 1975: Approximation of terrestrial lead isotope evolution by a 2-stage model. Earth and Planetary Science Letters 26, 207-221.

Vander Auwera, J., Bolle, O., Bingen, B., Liégeois, J.-P., Bogaerts, M., Duchesne, J.-C., DeWaele, B. \& Longhi, J. 2011: Sveconorwegian massif-type anorthosites and related granitoids result from postcollisional melting of a continental arc root. Earth Science Review 107, 375-397. 